\title{
ANALISIS PENGARUH PERANAN INTERNAL AUDIT TERHADAP EFEKTIVITAS PROSEDUR PENAGIHAN PIUTANG USAHA PADA PT ADIRA DINAMIKA MULTI FINANCE
}

\author{
Lusiana Lumentut \\ Ventje Ilat \\ Sifrid S. Pangemanan \\ Fakultas Ekonomi dan Bisnis Jurusan Akuntansi
Universitas Sam Ratulangi Manado
Email : lucyanalumentut@yahoo.com
}

\begin{abstract}
ABSTRAK
PT Adira Dinamika Multi Finance adalah perusahaan yang bergerak dibidang jasa pembiayaan. Sehingga, aktivitas penagihan piutang menjadi bagian yang penting dalam melancarkan distribusi pendapatan perusahaan yang selanjutnya digunakan sebagai modal kerja dan kelancaran perputaran aktiva perusahaan secara berkelanjutan. Penelitian ini bertujuan untuk mengetahui, menggambarkan dan menjelaskan Pengaruh Peranan Internal Audit Terhadap Efektivitas Prosedur Penagihan Piutang Usaha. Variabel yang diteliti dalam penelitian ini adalah Peranan Internal Audit (X) sebagai variabel independent dan Efektivitas Prosedur Penagihan Piutang Usaha (Y) sebagai variabel dependent. Metode yang digunakan adalah metode penelitian kuantitatif lalu dideskripsikan dengan tujuan untuk mengetahui hubungan atau pengaruh antar variabel melalui pendekatan kuantitatif dan tes statistik. Hasil penelitian yang didapat dari hasil uji statistik chi-square sebesar 9,56 dimana hitung > tabel $(9,56>3,84)$ yang berarti ada pengaruh yang sangat kuat antara kedua variabel, dengan demikian hasil uji hipotesis dapat diterima, sehingga dapat disimpulkan bahwa peranan internal audit berpengaruh terhadap efektivitas prosedur penagihan piutang usaha.
\end{abstract}

\section{Kata Kunci : Internal Audit, Efektivitas, Prosedur Penagihan Piutang.}

\section{ABSTRACT}

PT Adira Dinamika Multi Finance is a company engaged in financial services. Thus, the collection of accounts receivable activity becomes an important part in the conduct of the company's revenue distribution was then used as working capital and asset turnover smoothness sustainable company. This study aims to determine, describe and explain the Influence of role Internal Audit Against Effectiveness Procedures Billing Accounts Receivable. The variables examined in this study is the role of Internal Audit $(X)$ as the independent variable and Accounts Receivable Billing Procedures Effectiveness ( $Y$ ) as the dependent variable. The method used is quantitative method then describe that aims to determine relationships or influence between variables through a quantitative approach and statistical tests. The results that has obtained of tests conducted of chi-square statistic is 9.56 where hitung > tabel (9.56>3.84), which means there is a very strong influence between the two variables, with thus the hypothesis test results are acceptable, so it can be concluded that the role of internal audit affect the effectiveness procedures of the collection of accounts receivable.

Keywords : Internal Audit, Effectiveness, Accounts Receivable Billing Procedures 


\section{PENDAHULUAN}

\section{Latar Belakang}

Berkembangnya dunia bisnis saat ini, menuntut para pelaku bisnis untuk mengikuti perkembangannya. Dalam menjalankan usahanya, sangat sedikit perusahaan yang menggunakan cash and carry dalam kegiatan transaksi jual beli berupa barang ataupun jasa, melainkan lebih banyak yang menggunakan transaksi penjualan barang atau jasa secara kredit. Dimana, dalam kasus pembelian barang mewah seperti mobil ataupun motor, perusahaan-perusahaan yang menjual otomotif seperti yang telah disebutkan tidak banyak yang ingin mengambil resiko piutang tak tertagih. Hal ini menjadi salah satu alassan perusahaan penjualan otomotif banyak bekerja sama dengan perusahaan pembiayaan. Dalam hal ini perusahaan pembiayaan inilah yang berhubungan langsung dengan konsumen yang menginginkan barang secara kredit sehingga menyebabkan terjadinya piutang usaha.

PT. Adira Dinamika Multi Finance adalah perusahaan yang bergerak di di sektor pembiayaan konsumen bidang otomotif. Dalam upaya meningkatkan laba yang semaksimal mungkin, PT. Adira Dinamika Multi Finance melayani konsumen yang hendak mengajukan pembiayaan atas kepemilikan barang mewah seperti sepeda motor atau mobil.

Seiring berjalannya waktu dalam kegiatan usaha atas aktivitas pembiayaan kepada konsumen menimbulkan piutang usaha. Bagian penagihan piutang menjadi bagian yang penting dalam melancarkan distribusi pendapatan perusahaan sebagai modal kerja dan kelancaran perputaran aktiva perusahaan secara berkelanjutan. Tetapi, meskipun demikian bagian penagihan piutang usaha terkadang tidak dikendalikan dengan baik, karena sering kali terjadi adanya keterlambatan dalam melakukan penyetoran dari hasil penagihan piutang dari waktu yang telah ditargetkan oleh perusahaan serta sering terjadi manipulasi data penagihan piutang, selain itu dengan keterlambatan penyetoran hasil penagihan piutang dan manipulasi data tersebut, dapat menghambat modal kerja tertahan dan perputaran aktiva akan terhambat yang dapat menyebabkan perusahaan menimbulkan kerugian yang cukup besar.

Semakin berkembangnya perusahaan yang diikuti pula oleh bertambahnya kegiatan, jumlah karyawan serta organisasi yang otomatis menimbulkan masalah-masalah baru yang lebih rumit. Maka, pimpinan akan menghadapi kesulitan dalam mengawasi dan mengendalikan segala sesuatu yang terjadi dalam perusahaannya karena keterbatasan kemampuan, tenaga dan waktu dalam mengatasi masalah tersebut. Sehingga dalam menunjang efektivitas penagihan piutang, diperlukan suatu pengendalian intern melalui adanya suatu bagian dalam perusahaan yang bertugas menilai kelayakan dan efektivitas pengelolaan yang ada dan menilai kualitas kegiatan yang telah dijalankan perusahaan. Bagian ini disebut bagian Internal Audit.

Penilaian yang objektif dan independen yang dilakukan oleh internal auditor akan menunjang efektivitas pengendalian internal khususnya penagihan piutang usaha. Internal Audit harus melakukan pengendalian terhadap prosedur penagihan piutang, agar menjamin bahwa proses penagihan piutang telah sesuai dengan persyaratan serta prosedur yang telah ditetapkan dalam Standard Operational Prosedur (SOP) sebagai pedoman atau panduan bagi seluruh personel atau sumber daya manusia (SDM) dalam melakukan aktivitas perusahaan dan sebagai alat pengendalian bagi manajemen untuk menghindari berbagai kerugian yang berpotensi terjadi.

PT Adira Dinamika Multi Finance adalah perusahaan yang bergerak dibidang pembiayaan dimana piutang merupakan asset yang sangat berharga, sehingga fungsi internal audit merupakan hal yang sangat penting dalam menunjang kinerja perusahaan. Berdasarkan uraian diatas maka penulis tertarik untuk melakukan penelitian dengan judul mengenai analisis pengaruh peranan internal audit terhadap efektivitas prosedur penagihan piutang usaha pada PT Adira Dinamika Multi Finance Manado.

\section{Tujuan Penelitian}

Tujuan dalam penelitian ini adalah untuk mengetahui pengaruh peranan internal audit terhadap efektivitas prosedur penagihan piutang usaha atas jasa pembiayaan pada PT Adira Dinamika Multi Finance Manado.

\section{Pengertian Internal Audit}

\section{TINJAUAN PUSTAKA}

Menurut Hiro Tugiman (2008:11) mendefinisikan internal audit adalah suatu fungsi penilaian yang independen dalam suatu organisasi untuk menguji dan mengevaluasi kegiatan organisasi yang dilaksanakan. 
Sedangkan menurut Institute of Internal Auditors (IIA) yang dikutip oleh Randal J. Elder, Mark S. Beasley, Alvin A. Arens (20011:482) mendefinisikan internal audit adalah aktivitas konsultasi dan assurance yang objektif dan independen yang dirancang untuk menambah nilai dan memperbaiki operasi organisasi.

Dari kedua definisi di atas dapat disimpulkan bahwa internal audit merupakan kegiatan penilaian bebas, dipersiapkan dalam organisasi sebagai suatu jasa dengan cara memeriksa dan menilai efektivitas kegiatan unit lain untuk memperbaiki kinerja perusahaan.

\section{Tujuan Internal Audit}

Menurut Akmal (2006:5) menyatakan bahwa tujuan pemeriksaan intern adalah membantu organisasi dalam mencapai tujuannya dengan melalui pendekatan yang sistematis, disiplin untuk mengevaluasi dan melakukan perbaikan atas keefektivan manajemen risiko, pengendalian dan proses yang jujur, bersih dan baik.

Sedangkan menurut Sukirno Agoes (2004:222) mengemukakan tujuan pemeriksaan dilakukan oleh internal auditor adalah:"Untuk membantu semua pimpinan perusahaan (manajemen) dalam menyelesaikan tanggung jawabnya dengan memberikan analisa, penilaian dan komentar mengenai kegiatan dalam pemeriksaan.

Dari kedua definisi diatas dapat disimpulkan bahwa tujuan internal audit adalah membantu para anggota organisasi agar dapat melaksanakan tanggung jawabnya secara efektif. Untuk itu, internal auditor akan melakukan analisis, penilaian dan mengajukan saran-saran.

\section{Ruang Lingkup Internal Audit}

Ruang lingkup internal audit adalah mengenai keefektifan sistem pengendalian internal serta pengevaluasian terhadap kelengkapan dan keefektifan sistem pengendalian internal yang memiliki organisasi, serta kualitas pelaksanaan tanggung jawab yang diberikan.

Ruang lingkup kegiatan internal audit menurut Hiro Tugiman (2006 :99) menerangkan bahwa aktivitasaktivitas internal audit harus meliputi ruang lingkup sebagai berikut:

1. Meninjau sistem yang telah ditetapkan untuk memastikan kesesuaiannya dengan berbagai kebijaksanaan, rencana, prosedur, hukum dan peraturan yang dapat berakibat penting terhadap kegiatan organisasi, serta harus menentukan apakah organisasi telah tercapai kesesuaian dengan hal-hal tersebut.

2. Meninjau cara yang dipergunakan untuk melindungi harta dan bila dipandang perlu memverifikasi keberadaan harta-harta tersebut.

3. Menilai keekonomisan dan keefisienan penggunaan berbagai sumberdaya.

4. Meninjau berbagai operasi dan program untuk menilai apakah hasil konsisten dengan tujuan dan sasaran yang telah ditetapkan dan apakah kegiatan atau program tersebut dilaksanakan sesuai dengan yang direncanakan.

\section{Kriteria Internal Audit}

Menurut Randal J. Elder, Mark S. Beasley, Alvin A. Arens dan Amir Abadi Yusuf (2011:5) menyatakan bahwa terdapat dua hal yang harus dimiliki oleh seorang auditor yaitu ia harus independen dan kompeten.

Para pemeriksa internal harus mematuhi standar professional dalam melakukan pemeriksaan.Kode etik menetapkan standar profesi dan menetapkan dasar bagi pelaksananya.Kode etik menghendaki standar yang tinggi bagi kejujuran, sikap objektif, ketekunan, dan loyalitas yang harus dipenuhi oleh pemeriksa internal. Standar profesioanal audit internal yang harus dipenuhi dalam melakukan pemeriksaan diantaranya:

a. Pengetahuan dan kecakapan.

b. Hubungan antarmanusia dan komunikasi.

c. Pendidikan berkelanjutan.

d. Ketelitian professional.

\section{Pelaksanaan Internal Audit}

Menurut Hiro Tugiman (2008:53) pelaksanaan internal audit meliputi:

1. Perencanaan harus didokumentasikan dan mencakup:

a. Menetapkan tujuan dan ruang lingkup pekerjaan.

b. Menentapkan informasi mengenai aktivitas yang diperiksa.

c. Menentukan sumber-sumber yang penting dalam melaksanakan audit. 

d. Mengkomunikasikan dengan pihak-pihak tertentu.
e. Melakukan survey langsung.
f. Menulis program audit.
g. Menentukan kapan, kepada siapa hasil audit dikomunikasikan.
h. Mendapatkan persetujuan dan perencanaan audit.

2. Pengujian dan pengevaluasian informasi

a. Seluruh informasi yang berehubungan dengan tujuan dan ruang lingkup dikumpulkan.

b. Prosedur audit termasuk teknik pengujian dan sample harus dipilih proses pengumpulan analisis dan intrepretasi serta dokumentasi harus diawasi untuk memelihara objektivitas.

3. Internal audit harus melaporkan hasil audit:

a. Laporan ditulis setelah pekerjaan audit selesai.

b. Audit internal harus mendiskusikan kesimpilan-kesimpulan dan rekomendasi-rekomendasi dengan pihak manajemen.

c. Laporan audit harus objektif dan jelas, ringkas, konstruktif dan tepat waktu.

d. Laporan harus mencakup rekomendasi untuk pemeliharaan dan pernyataan keberhasilan pelaksanaan disertai tindakan koreksi.

e. Laporan menyatakan tujuan, ruang lingkup dan hasil pemeriksaan.

4. Pemeriksaan internal harus melakukan tindak lanjut untuk memastikan tindakan yang pantas telah dilakaukan.

\section{Efektivitas}

Menurut Mahmudi (2007:84) mendefinisikan efektivitas merupakan hubungan antara output dengan tujuan, semakin besar kontribusi (sumbangan) output terhadap pencapaian tujuan, maka semakin efektif organisasi, program atau kegiatan.

\section{Prosedur}

Menurut Mulyadi (2007:5) mengemukakan definisi prosedur adalah suatu kegiatan yang melibatkan beberapa orang dalam satu departemen atau lebih, yang dibuat untuk menjamin penanganan secara seragam transaksi perusahaan yang terjadi secara berulang-ulang.

\section{Piutang}

Menurut Rusdi Akbar (2004:199) menyatakan bahwa piutang meliputi semua hak atau klaim perusahaan pada organisasi lain untuk menerima sejumlah kas, barang, atau jasa di masa yang akan datang sebagai akibat kejadian pada masa yang lalu.

\section{Prosedur Penagihan Piutang}

Setelah terjadi piutang maka akan dilakukan penagihan terhadap para debitur. Penagihan sebaiknya dilakukan oleh petugas yang khusus ditunjuk untuk melakukan penagiha piutang, yang disebut dengan kolektor. Adapun proses penagihan piutang menurut Indriyo dan Basri (2002:83) diantaranya:

a. Bagian piutang menyusun daftar tagihan piutang yang jatuh tempo. Daftar tersebut akan diserahkan kepada penagih beserta kuitansi penjualan asli.

b. Penagih langsung mendatangi pelanggan ke alamat masing-masing dan menagih piutang yang tercantum pada daftar tagihan. Setiap pelunasan yang dilakukan pelanggan akan diberikan kuitansi penjualan yang asli yang dicap lunas.

c. Uang hasil penagihan yang diperoleh akan diserahkan kepada kasir serta daftar tagihannya.

d. Kasir menghitung uang tagihan dan apabila sudah cocok dengan daftar tagihan maka daftar tagihan tersebut akan diberikan cap dimana tagihan tersebut telah diterima oleh kasir. Setelah dicap daftar tagihan tersebut akan diserahkan kembali kepada penagih atau kolekor.

e. Selanjunya bagian penagihan akan menyerahkan daftar tagihan ke bagian piutang dan akuntansi, penagihan piutang yang diterima pada buku tambahan dan bagian akuntansi mencatat ke buku kasir dan buku besar. 
Beberapa cara yang dapat dilakukan untuk melakukan proses penagihan piutang menurut Menurut Kasmir (2003:95) yaitu:

a. Melalui Surat

Bilamana pembayaran hutang dari pelanggan sudah lewat beberapa hari tetapi belum dilakukan pembayaran maka perusahaan dapat mengirim surat untuk mengingatkan atau menegur pelanggan yang belum membayar hutangnya yang jatuh tempo.

b. Melalui Telepon

Apabila setelah pengiriman surat teguran ternyata tagihan tersebut belum juga dibayar maka bagian kredit dapat menelepon pelanggan dan secara pribadi memintanya untuk segera melakukan pembayaran.

c. Kunjungan Personal

Melakukan kunjungan secara personal atau pribadi ke tempat pelanggan sering kali digunakan karena dirasakan sangat penting dalam usaha-usaha pengumpulan piutang.

d. Tindakan Yuridis

Bilamana ternyata pelanggan tidak mau membayar kewajibannya maka perusahaan dapat menggunakan tindakan-tindakan hukum dengan mengajukan gugatan perdata melalui pengadilan.

\section{Tabel 1. Penelitian Terdahulu}

\begin{tabular}{|c|c|c|c|c|c|c|c|}
\hline No. & $\begin{array}{c}\text { Nama } \\
\text { Peneliti / } \\
\text { tahun }\end{array}$ & Judul & Tujuan & $\begin{array}{c}\text { Metode } \\
\text { Penelitian }\end{array}$ & Hasil Penelitian & Persamaan & Perbedaan \\
\hline 1. & $\begin{array}{l}\text { Moh. } \\
\text { Taufan } \\
\text { Supadrijo } \\
\text { no (2006) }\end{array}$ & $\begin{array}{l}\text { Pengaruh audit } \\
\text { internal dalam } \\
\text { menunjang } \\
\text { efektivitas } \\
\text { pengendalian } \\
\text { internal piutang } \\
\text { usaha pada PT. } \\
\text { Telekomunikasi } \\
\text { Indonesia Divre } \\
\text { II }\end{array}$ & $\begin{array}{l}\text { Untuk } \\
\text { mengetahui } \\
\text { pengaruh audit } \\
\text { internal dalam } \\
\text { menunjang } \\
\text { efektivitas } \\
\text { pengendalian } \\
\text { internal piutang } \\
\text { usaha atas kredit } \\
\text { yang terjadi pada } \\
\text { PT. } \\
\text { Telekomunikasi } \\
\text { Indonesia Divre } \\
\text { II. }\end{array}$ & Kuantitatif. & $\begin{array}{l}\text { Audit internal } \\
\text { yang } \\
\text { dilaksanakan } \\
\text { pada PT. } \\
\text { Telekomunikasi } \\
\text { Indonesia Divre } \\
\text { II sudah } \\
\text { memadai } \\
\text { sehingga } \\
\text { berpengaruh } \\
\text { dalam } \\
\text { menunjang } \\
\text { efektivitas } \\
\text { pengendalian } \\
\text { internal piutang } \\
\text { usaha. }\end{array}$ & $\begin{array}{l}\text { Peneliti } \\
\text { sebelumnya } \\
\text { telah } \\
\text { melakukan } \\
\text { penelitian } \\
\text { terhadap } \\
\text { variabel yang } \\
\text { sama yaitu } \\
\text { audit internal } \\
\text { dan piutang } \\
\text { usaha. }\end{array}$ & $\begin{array}{l}\text { Objek yang } \\
\text { diteliti berbeda. } \\
\text { Peneliti } \\
\text { sebelumnya } \\
\text { menggunakan } \\
\text { korelasi rank- } \\
\text { spearman untuk } \\
\text { uji pengaruh } \\
\text { sedangkan } \\
\text { peniliti } \\
\text { menggunakan uji } \\
\text { statistik chi- } \\
\text { square. }\end{array}$ \\
\hline 2. & $\begin{array}{l}\text { Sulaeman } \\
\text { (2012) }\end{array}$ & $\begin{array}{l}\text { Analisis prosedur } \\
\text { pengendalian } \\
\text { intern piutang } \\
\text { usaha pada Astra } \\
\text { Credit } \\
\text { Companies Cab. } \\
\text { Makassar }\end{array}$ & $\begin{array}{l}\text { Untuk } \\
\text { mengetahui } \\
\text { apakah } \\
\text { pengendalian } \\
\text { intern yang telah } \\
\text { dilakukan oleh } \\
\text { Astra Kredit } \\
\text { Companies Cab. } \\
\text { Makassar sudah } \\
\text { efektif dan sesuai } \\
\text { dengan prinsip } \\
\text { pengendalian } \\
\text { intern piutang } \\
\text { usaha. }\end{array}$ & Deskriptif. & $\begin{array}{l}\text { Prosedur } \\
\text { pengendalian } \\
\text { piutang usaha } \\
\text { pada Astra Credit } \\
\text { Companies Cab. } \\
\text { Makassar } \\
\text { berjalan efektif, } \\
\text { dimana } \\
\text { manajemen } \\
\text { perusahaan } \\
\text { sudah } \\
\text { menerapkan } \\
\text { konsep dasar dan } \\
\text { prinsip-prinsip } \\
\text { pengendalian } \\
\text { intern. }\end{array}$ & $\begin{array}{l}\text { Peneliti } \\
\text { sebelumnya } \\
\text { telah } \\
\text { melakukan } \\
\text { penelitian } \\
\text { terhadap } \\
\text { variabel yang } \\
\text { sama yaitu } \\
\text { prosedur } \\
\text { pengendalian } \\
\text { akan piutang } \\
\text { usaha. }\end{array}$ & $\begin{array}{l}\text { Penelitian } \\
\text { sebelumnya } \\
\text { hanya meneliti } \\
\text { satu variabel dan } \\
\text { metode yang } \\
\text { digunakan adalah } \\
\text { deskriptif } \\
\text { sedangkan } \\
\text { peniliti sekarang } \\
\text { menggunakan } \\
\text { metode } \\
\text { kuantitatif dalam } \\
\text { penelitian. }\end{array}$ \\
\hline
\end{tabular}

Sumber: Data Olahan 


\section{Hipotesis}

Penetapan hipotesis nol (Ho) dan hipotesis alternatif (Ha) digunakan dengan tujuan mengetahui ada tidaknya pengaruh antara internal audit terhadap efektivitas prosedur penagihan piutang. Perumusan Ho dan Ha sebagai berikut:

Ho $=0$ tidak terdapat pengaruh antara peranan internal audit terhadap efektivitas prosedur penagihan piutang $\mathrm{Ha} \neq 0$ terdapat pengaruh antara peranan internal audit terhadap efektivitas prosedur penagihan piutang

\section{Jenis Penelitian}

\section{METODE PENELITIAN}

Jenis penelitian yang digunakan adalah jenis penelitian berbentuk penelitian kuantitatif lalu mendeskripsikannya dengan tujuan untuk mengetahui pengaruh atau hubungan antar variabel, melalui pendekatan kuantitatif dan tes statistik.

\section{Tempat dan Waktu Penelitian}

Penelitian ini dilakukan pada PT Adira DInamika Multi Finance Manado, Jl. Ahmad Yani No. 10 D-E Sario, Manado, Kode Pos 95114. Waktu dilakukannya penelitian ini yaitu akhir bulan November 2013 sampai bulan Januari 2014.

\section{Prosedur Penelitian}

Adapun prosedur dalam penelitian ini adalah sebagai berikut:

1. Menetapkan judul penelitian.

2. Mengidentifikasi dan merumuskan masalah.

3. Menentukan metode penelitian yang akan digunakan.

4. Pengumpulan data yang dilakukan pada PT Adira Dinamika Multi Finance Manado.

5. Pengolahan dan analisis data yang telah dikumpulkan.

6. Merumuskan hasil penelitian dan pembahasan.

7. Menarik kesimpulan dari hasil penelitian dan memberikan saran.

\section{Populasi dan Sampel}

Populasi adalah kelompok elemen yang lengkap, yang biasanya berupa orang, objek, transaksi, atau kejadian dimana kita tertarik untuk mempelajarinya atau menjadi objek penelitian. (Kuncoro, 2001:bab 3). Populasi penelitian ini adalah seluruh karyawan PT. Adira Dinamika Multi Finance yang berjumlah 76 karyawan.

Sampel adalah suatu himpunan bagian (subset) dari unit populasi. (Kuncoro, 2001:bab 3). Pengambilan sampel penelitian menggunakan metode random sampling dimana sampel diambil dari separuh jumlah populasi yang diperlukan yaitu 34 orang. Terdiri dari 9 orang bagian finance, 11 orang ARO (Account Receivable Officer), 4 orang remedial admin, 6 orang messanger. 2 orang teller, 2 orang customer services.

\section{Teknik Pengumpulan Data}

Teknik pengumpulan data untuk penelitian ini adalah sebagai berikut :

1. Wawancara, yaitu suatu teknik pengumpulan data dengan melaksanakan tanya jawab langsung kepada pegawai yang mempunyai wewenang untuk memberikan data dan informasi yang diperlukan dalam penulisan.

2. Kuesioner, yaitu teknik pengumpulan data dengan cara memberi seperangkat pertanyaan tertulis kepada responden untuk menjawabnya.

3. Observasi, yaitu teknik pengumpulan data dengan mengadakan pengamatan secara langsung atau seksama pada pelaksanaan operasi perusahaan atau instansi, sejalan dengan judul diatas agar mendapatkan data yang objektif dan sistematis.

4. Library Research, yaitu suatu teknik pengumpulan data dengan cara membaca buku-buku, referensi dan literature yang berhubungan dengan penyusunan laporan akhir. 


\section{Metode Analisis Data}

Variabel Internal Audit dan Efektivitas Prosedur Penagihan Piutang Dagang diukur menggunakan skala Likert. Skala Likert menurut Sugiyono (2008:132), dalam bukunya metode penelitian bisnis adalah skala yang digunakan untuk mengukur sikap, pendapat, dan presepsi sesorang atau sekelompok orang tentang fenomena sosial.

Kuesioner yang digunakan penulis bersifat tertutup dengan jawaban yang sudah ditentukan terlebih dahulu dan tidak ada jawaban yang lain. Jawaban setiap instrumen yang menggunakan skala likert mempunyai gradasi dari sangat positif sampai negatif serta jawaban itu dapat diberi skor, yaitu:
a. Sangat Setuju/selalu/sangat positif diberi
skor 5
b. Setuju/sering/positif diberi
skor 4
c. Ragu-ragu/kadang-kadang/netral diberi
skor 3
d. Kurang Setuju/hampir tidak pernah/negatif diberi skor 2
e. Tidak setuju/tidak pernah/diberi
skor 1

Untuk menilai variabel $\mathrm{x}$ dan variabel $\mathrm{y}$, maka anlisis yang digunakan berdasarkan rata-rata dan masingmasing variabel. Nilai rata-rata didapat dengan menjumlahkan data keseluruhan dalam setiap variabel, kemudian dibagi dengan jumlah responden dan selanjutnya untuk menetukan rata-rata tersebut digunakan rumus rata-rata yang terdapat pada buku statistik untuk penelitian karangan sugiyono (2008:43), sebagai berikut:

$$
\begin{aligned}
& \text { keterangan: } \mathrm{x}=\text { rata-rata nilai } \mathrm{x} \quad \mathrm{n}=\text { jumlah responden } \quad \mathrm{y}=\text { rata-rata nilai } \mathrm{y} \\
& \text { me }=\text { rata-rata mean } \quad x i=\text { nilai } x \text { ke-i sampai ke-n } \quad \text { yi }=\text { nilai } y \text { ke-i sampai ke-n }
\end{aligned}
$$

Setelah didapat rata-rata (mean) dari masing-masing variabel kemudian dibandingkan dengan kriteria yang penulis tentukan berdasarkan nilai terendah dan nilai tertinggi dari hasil kuesioner.

Nilai variabel $\mathrm{x}$ terdapat 20 pertanyaan, nilai tertinggi variabel $\mathrm{x}$ adalah 5 sehingga $(5 \times 20=100)$ sedangkan nilai terendah varibel $\mathrm{x}$ adalah 1 sehingga $(1 \times 20=20)$, untuk nilai variabel y terdapat 15 pertanyaan, nilai tertinggi variabel y adalah 5 sehingga $(5 \times 15=75)$ sedangkan nilai terendah variabel y adalah 1 sehingga $(1 \times 15=15)$.

Atas dasar nilai tertinggi dan terendah tersebut, maka dapat ditentukan rentang interval yaitu total nilai tertinggi dikurangi total nilai terendah dibagi jumlah kriteria. Dengan demikian, dapat ditentukan panjang interval kelas masing-masing variabel adalah sebagai berikut:

1. Kriteria untuk menilai peranan internal audit (variabel $x$ ) pada suatu perusahaan. Rentang $(100-20=80)$ jadi $80: 5=16$, dengan demikian dapat diperoleh kriteria penilaian sebagai berikut:
a. 84 - 100 dengan kriteria sangat memadai
b. 68 - 83 dengan kriteria memadai
c. 52 - 67 dengan kriteria cukup memadai
d. 36 - 51 dengan kriteria kurang memadai
e. 20 - 35 dengan kriteria tidak memadai

2. Kriteria untuk menilai efektivitas prosedur penagihan piutang (variabel y) pada suatu perusahaan. Rentang (75

$-15=60$ ) jadi $60: 5=12$, dengan demikian dapat diperoleh kriteria penilaian sebagai berikut:

a. $63-75$ dengan kriteria sangat efektif

b. 51 - 62 dengan kriteria efektif

c. 38 - 50 dengan kriteria cukup efektif

d. 25 - 37 dengan kriteria kurang efektif

e. 12-24 dengan kriteria tidak efektif

\section{Pengujian Hipotesis}

Hipotesis akan diuji dengan menggunakan statistik Chi Square dengan menggunakan rumus (M. Iqbal Hasan,MM) yaitu:
Dimana :

$$
\mathrm{X}^{2}=\text { Nilai } \mathrm{X}^{2} \text { hitung }
$$$$
\text { Df }=\text { [baris - 1] [kolom - 1] }
$$$$
\begin{aligned}
& n=\text { Jumlah Populasi } \\
& \alpha=5 \%
\end{aligned}
$$ 
Uji Chi Square berguna untuk menguji hubungan atau pengaruh dua buah variabel nominal dan mengukur kuatnya hubungan antara variabel yang satu dengan variabel nominal lainnya.

\section{Sejarah Singkat PT Adira Dinamika Multi Finance}

\section{HASIL DAN PEMBAHASAN}

PT Adira Dinamika Multi Finance atau Adira Finance didirikan pada tahun 1990 dan mulai beroperasi pada tahun 1991. Sejak awal Perusahaan telah berkomitmen untuk menjadi perusahaan yang terbaik dan terkemuka di sektor pembiayaan yang melayani pembiayaan beragam merek, baik untuk sepeda motor maupun mobil, baru maupun bekas. Melihat pada adanya potensi untuk mengembangkan usaha lebih lanjut, Adira Finance melakukan penawaran umum perdana atas sahamnya pada tahun 2003, yang mana Bank Danamon menjadi pemegang saham mayoritas.

\section{Struktur Organisasi PT Adira Dinamika Multi Finance Manado}

Struktur organisasi pada PT Adira Dinamika Multi Finance Manado dipimpin oleh seorang Branch Manager dan seorang branch HRDGA Head yang membawahi Marketing Head, Credit Analyst, Account Receivable Head, Administration Head, dan Operation Head yang mempunyai tugas dan wewenang masing.

\section{Hasil Penelitian dan Pembahasan}

\section{A. Tanggapan Responden Mengenai Peranan Internal Audit (X)}

Deskripsi untuk variabel X (Peranan Internal Audit) dilakukan dengan menghitung sebaran jawaban responden atas item pernyataan mengenai peranan internal audit yang terdiri dari 20 pertanyaan. Hal ini dapat ditunjukan dalam tabel sebagai berikut :

TABEL 2

Tanggapan Responden Mengenai Peranan Internal Audit pada PT Adira DinamikaMulti Finance

\begin{tabular}{|c|c|c|c|c|c|c|c|c|c|c|c|c|c|c|c|c|c|c|c|c|c|}
\hline \multirow[b]{2}{*}{ Pertanyaan: } & \multicolumn{20}{|c|}{ Jumlah Skor per item pertanyaan variabel X } & \multirow{2}{*}{ Total } \\
\hline & 1 & 2 & 3 & 4 & 5 & 6 & 7 & 8 & 9 & 10 & 11 & 12 & 13 & 14 & 15 & 16 & 17 & 18 & 19 & 20 & \\
\hline Jumlah & & & & & & & & & & & & & & & & & & & & & \\
\hline $\begin{array}{c}\text { Skor } \\
\mathbf{3 4}\end{array}$ & 156 & 150 & 150 & 156 & 154 & 152 & 146 & 150 & 148 & 148 & 150 & 148 & 152 & 152 & 150 & 152 & 152 & 150 & 152 & 142 & 3010 \\
\hline
\end{tabular}

\section{Sumber: Diolah dari data primer}

Berdasarkan tabel 2 diatas, dengan kriteria perhitungan yang telah ditetapkan, sebagai berikut:

$$
m e=-\quad m e=88,53
$$

Berdasarkan perhitungan diatas, maka dapat dipastikan bahwa tanggapan responden mengenai peranan internal audit memiliki skor total rata-rata 88,53 yang termasuk kedalam golongan interval $84-100$. Dengan demikian, peranan internal audit pada PT Adira Dinamika Multi Finance tergolong kedalam kriteria Sangat Memadai. Hal ini dapat dilihat dari indikator-indikator sebagai berikut:

1. Kriteria Auditor

TABEL 3

Presentase Jawaban Responden Mengenai Kriteria Auditor

\begin{tabular}{|c|c|c|c|c|c|c|c|c|c|c|}
\hline \multirow{2}{*}{ Pertanyaan } & \multicolumn{5}{|c|}{ Frekuensi Jawaban Berdasarkan Peringkat Jawaban } & \multicolumn{5}{|c|}{ Persentase Jawaban (\%) } \\
\hline & 5 & 4 & 3 & 2 & 1 & 5 & 4 & 3 & 2 & 1 \\
\hline $\mathrm{P} 1$ & 20 & 14 & 0 & 0 & 0 & 0.59 & 0.41 & 0.00 & 0.00 & 0.00 \\
\hline $\mathrm{P} 2$ & 14 & 20 & 0 & 0 & 0 & 0.41 & 0.59 & 0.00 & 0.00 & 0.00 \\
\hline P3 & 14 & 20 & 0 & 0 & 0 & 0.41 & 0.59 & 0.00 & 0.00 & 0.00 \\
\hline P4 & 20 & 14 & 0 & 0 & 0 & 0.59 & 0.41 & 0.00 & 0.00 & 0.00 \\
\hline P5 & 18 & 16 & 0 & 0 & 0 & 0.53 & 0.47 & 0.00 & 0.00 & 0.00 \\
\hline P6 & 16 & 18 & 0 & 0 & 0 & 0.47 & 0.53 & 0.00 & 0.00 & 0.00 \\
\hline P7 & 10 & 24 & 0 & 0 & 0 & 0.29 & 0.71 & 0.00 & 0.00 & 0.00 \\
\hline P8 & 14 & 20 & 0 & 0 & 0 & 0.41 & 0.59 & 0.00 & 0.00 & 0.00 \\
\hline P9 & 12 & 22 & 0 & 0 & 0 & 0.35 & 0.65 & 0.00 & 0.00 & 0.00 \\
\hline P10 & 15 & 16 & 3 & 0 & 0 & 0.44 & 0.47 & 0.09 & 0.00 & 0.00 \\
\hline P11 & 14 & 20 & 0 & 0 & 0 & 0.41 & 0.59 & 0.00 & 0.00 & 0.00 \\
\hline $\mathrm{P} 12$ & 12 & 22 & 0 & 0 & 0 & 0.35 & 0.65 & 0.00 & 0.00 & 0.00 \\
\hline Total & 179 & 226 & 3 & 0 & 0 & 5.26 & 6.65 & 0.09 & 0.00 & 0.00 \\
\hline Rata-Rata & & & & & & 0.44 & 0.55 & 0.01 & 0.00 & 0.00 \\
\hline
\end{tabular}


Dari tabel diatas, dapat dilihat bahwa berdasarkan tanggapan responden mengenai kriteria auditor dalam peranan internal audit berdasarkan peringkat jawaban yang telah ditetapkan, dari sejumlah responden sebanyak 34 orang, sebanyak $0,44 \%$ menjawab sangat setuju, $0,55 \%$ menjawab setuju dan $0,01 \%$ menjawab ragu-ragu. Dengan demikian responden lebih banyak menjawab pada interval setuju dan sangat setuju dengan jumlah rata-rata $0.99 \%$, dimana, dalam hal ini indepedensi sangat diperlukan dan dilaksanakan oleh seorang internal auditor dalam melakukan tugas pemeriksaan. Dari hasil jawaban responden diatas dapat disimpulkan bahwa kriteria seorang internal audit pada PT Adira Dinamika Multi Finance sudah dikatakan telah memenuhi kriteria sebagai seorang internal auditor.

2. Ruang Lingkup

TABEL 4

Persentase Jawaban Responden mengenai Ruang Lingkup

\begin{tabular}{ccccccccccc}
\hline \multirow{2}{*}{ Pertanyaan } & \multicolumn{1}{c}{ Frekuensi Jawaban Berdasarkan Peringkat Jawaban } & \multicolumn{5}{c}{ Persentase Jawaban (\%) } \\
& 5 & 4 & 3 & 2 & 1 & 5 & 4 & 3 & 2 & 1 \\
\hline P13 & 16 & 18 & 0 & 0 & 0 & 0.47 & 0.53 & 0.00 & 0.00 & 0.00 \\
\hline P14 & 16 & 18 & 0 & 0 & 0 & 0.47 & 0.53 & 0.00 & 0.00 & 0.00 \\
\hline P15 & 14 & 20 & 0 & 0 & 0 & 0.41 & 0.59 & 0.00 & 0.00 & 0.00 \\
\hline P16 & 16 & 18 & 0 & 0 & 0 & 0.47 & 0.53 & 0.00 & 0.00 & 0.00 \\
\hline Total & 62 & 74 & 0 & 0 & 0 & 1.82 & 2.18 & 0.00 & 0.00 & 0.00 \\
\hline Rata-Rata & & & & & & & & & &
\end{tabular}

Sumber: Diolah dari data primer

Dari tabel diatas, dapat dilihat bahwa berdasarkan tanggapan responden mengenai kompetensi dalam peranan internal audit. Berdasarkan tabel 4.3 diatas bahwa dari sejumlah responden sebanyak 34 orang sebanyak $0,46 \%$ menjawab sangat setuju dan $0,54 \%$ menjawab setuju. Dengan demikian responden lebih banyak menjawab setuju dengan rata-rata sebanyak $0,54 \%$. Dari hasil jawaban responden mengenai ruang lingkup dapat disimpulkan bahwa internal audit melakukan pengujian dan evaluasi terhadap kecukupan dan keefektivan sistem pengendalian internal yang dimiliki oleh organisasi dan kualitas pelaksanaan tanggung jawab sudah baik dan memadai.

3. Langkah-Langkah Audit

TABEL 5

Presentase Jawaban Responden Mengenai Langkah-Langkah Audit

\begin{tabular}{cccccccccccc}
\hline \multirow{2}{*}{ Pertanyaan } & \multicolumn{1}{c}{ Frekuensi Jawaban Berdasarkan Peringkat Jawaban } & \multicolumn{5}{c}{ Persentase Jawaban (\%) } \\
& 5 & 4 & 3 & 2 & 1 & 5 & 4 & 3 & 2 & 1 \\
\hline P17 & 16 & 18 & 0 & 0 & 0 & 0.47 & 0.53 & 0.00 & 0.00 & 0.00 \\
\hline P18 & 14 & 20 & 0 & 0 & 0 & 0.41 & 0.59 & 0.00 & 0.00 & 0.00 \\
\hline P19 & 16 & 18 & 0 & 0 & 0 & 0.47 & 0.53 & 0.00 & 0.00 & 0.00 \\
\hline P20 & 11 & 18 & 5 & 0 & 0 & 0.32 & 0.53 & 0.15 & 0.00 & 0.00 \\
\hline Total & 57 & 74 & 5 & 0 & 0 & 1.68 & 2.18 & 0.15 & 0.00 & 0.00 \\
\hline Rata-Rata & & & & & & & & & & & \\
\hline
\end{tabular}

Sumber: Diolah dari data primer

Berdasarkan tabel 4.4 diatas bahwa tanggapan responden dari sejumlah responden sebanyak 34 orang, sebanyak $0,42 \%$ menjawab sangat setuju dan $0,54 \%$ menjawab setuju, dan $0,04 \%$ menjawab ragu-ragu. Dengan demikian responden lebih banyak menjawab pada interval setuju dan sangat setuju dengan jumlah rata-rata $0,96 \%$, jadi dapat disimpulkan bahwa internal audit pada PT Adira Dinamika Multi Finance sudah sesuai dengan langkahlangkah audit.

\section{B. Tanggapan Responden Mengenai Prosedur Penagihan Piutang Usaha}

Deskripsi untuk variabel Y (Efektivitas Prosedur Penagihan Piutang Usaha) dilakukan dengan menghitung sebaran jawaban responden atas item pernyataan mengenai Efektivitas Prosedur Penagihan Piutang Usaha yang terdiri dari 15 pertanyaan. Hal ini dapat ditunjukan dalam tabel berikut ini:

TABEL 6.

Tanggapan Responden Mengenai Efektivitas Prosedur Penagihan Piutang Usaha Pada PT Adira Dinamika Multi Finance

\begin{tabular}{|c|c|c|c|c|c|c|c|c|c|c|c|c|c|c|c|c|}
\hline \multirow[b]{2}{*}{ Pertanyaan: } & \multicolumn{15}{|c|}{ Jumlah Skor per item pertanyaan variabel Y } & \multirow{2}{*}{ Total } \\
\hline & 1 & 2 & 3 & 4 & 5 & 6 & 7 & 8 & 9 & 10 & 11 & 12 & 13 & 14 & 15 & \\
\hline Jumlah & & & & & & & & & & & & & & & & \\
\hline $\begin{array}{c}\text { Skor } \\
\mathbf{3 4} \\
\text { Responden }\end{array}$ & 154 & 160 & 154 & 160 & 152 & 150 & 156 & 158 & 154 & 150 & 140 & 152 & 144 & 144 & 150 & 2278 \\
\hline
\end{tabular}

Sumber: Diolah dari data primer

Berdasarkan tabel 6 diatas, maka tanggapan 34 responden mengenai efektivitas prosedur penagihan piutang usaha dapat dilihat dari perhitungan sebagai berikut: 


$$
\text { - } \quad m e=-\quad m e=67
$$

Berdasarkan perhitungan diatas, maka dapat dipastikan bahwa tanggapan responden mengenai efektivitas prosedur penagihan piutang usaha memiliki skor total rata-rata 67 yang termasuk kedalam golongan interval 63 75. Dengan demikian efektivitas prosedur penagihan piutang pada PT Adira Dinamika Multi Finance tergolong kedalam kriteria Sangat Efektif. Dimana prosedur penagihan piutang telah dijalankan dengan semestinya oleh bagian-bagian yang terkait pada prosedur penagihan piutang, sehingga perputaran modal kerja dan perputaran aktiva perusahaan dapat berjalan dengan baik.

Hal ini dapat dilihat dari indikator-indikator berikut:

1. Penyusunan Daftar Tagihan Piutang Yang Telah Jatuh Tempo

Berdasarkan sebaran jawaban responden untuk pernyataan mengenai efektivitas prosedur penagihan piutang usaha, maka tanggapan responden mengenai data piutang usaha dapat dilihat pada tabel berikut:

TABEL 7

Presentase Jawaban Responden Mengenai Penyusunan Daftar Tagihan Piutang Yang Jatuh Tempo

\begin{tabular}{|c|c|c|c|c|c|c|c|c|c|c|}
\hline \multirow{2}{*}{ Pertanyaan } & \multicolumn{5}{|c|}{ Frekuensi Jawaban Berdasarkan Peringkat Jawaban } & \multicolumn{5}{|c|}{ Persentase Jawaban (\%) } \\
\hline & 5 & 4 & 3 & 2 & 1 & 5 & 4 & 3 & 2 & 1 \\
\hline P1 & 18 & 16 & 0 & 0 & 0 & 0.53 & 0.47 & 0.00 & 0.00 & 0.00 \\
\hline P2 & 24 & 10 & 0 & 0 & 0 & 0.71 & 0.29 & 0.00 & 0.00 & 0.00 \\
\hline P3 & 18 & 16 & 0 & 0 & 0 & 0.53 & 0.47 & 0.00 & 0.00 & 0.00 \\
\hline $\mathrm{P} 4$ & 22 & 10 & 2 & 0 & 0 & 0.65 & 0.29 & 0.06 & 0.00 & 0.00 \\
\hline P5 & 16 & 18 & 0 & 0 & 0 & 0.47 & 0.53 & 0.00 & 0.00 & 0.00 \\
\hline P6 & 16 & 16 & 2 & 0 & 0 & 0.47 & 0.47 & 0.06 & 0.00 & 0.00 \\
\hline Total & 114 & 86 & 4 & 0 & 0 & 3.35 & 2.53 & 0.12 & 0.00 & 0.00 \\
\hline Rata-Rata & & & & & & 0.56 & 0.42 & 0.02 & 0.00 & 0.00 \\
\hline
\end{tabular}

Sumber: Diolah dari data primer

Berdasarkan tabel 4.6 diatas bahwa dari sejumlah responden sebanyak 34 orang sebanyak $0,57 \%$ menjawab sangat setuju dan 0,43\% menjawab setuju dan 0,02\% menjawab ragu-ragu. Dengan demikian responden lebih banyak menjawab pada interval sangat setuju dan setuju dengan jumlah rata-rata jawaban sebanyak 0,98\%. Dalam hal ini bagian piutang selalu melakukan pendataan terhadap pelanggan yang memiliki piutang yang telah jatuh tempo dan data tersebut diserahkan kepada bagian penagih untuk melakukan penagihan.

2. Penagih Langsung Mendatangi Pelanggan

Tabel 8

Presentase Jawaban Responden Mengenai Penagih Langsung Mendatangi Pelanggan

\begin{tabular}{|c|c|c|c|c|c|c|c|c|c|c|}
\hline \multirow{2}{*}{ Pertanyaan } & \multicolumn{5}{|c|}{ Frekuensi Jawaban Berdasarkan Peringkat Jawaban } & \multicolumn{5}{|c|}{ Persentase Jawaban (\%) } \\
\hline & 5 & 4 & 3 & 2 & 1 & 5 & 4 & 3 & 2 & 1 \\
\hline P7 & 20 & 14 & 0 & 0 & 0 & 0.59 & 0.41 & 0.00 & 0.00 & 0.00 \\
\hline P8 & 22 & 12 & 0 & 0 & 0 & 0.65 & 0.35 & 0.00 & 0.00 & 0.00 \\
\hline P9 & 18 & 16 & 0 & 0 & 0 & 0.53 & 0.47 & 0.00 & 0.00 & 0.00 \\
\hline Total & 60 & 42 & 0 & 0 & 0 & 1.76 & 1.24 & 0.00 & 0.00 & 0.00 \\
\hline Rata-Rata & & & & & & 0.59 & 0.41 & 0.00 & 0.00 & 0.00 \\
\hline
\end{tabular}

Sumber: Diolah dari Data Primer

Berdasarkan tabel 8 diatas bahwa dari sejumlah responden sebanyak 34 orang sebanyak $0,59 \%$ menjawab sangat setuju, dan $0,41 \%$ menjawab setuju. Dengan demikian responden lebih banyak menjawab pada interval sangat setuju dan setuju dengan jumlah rata-rata jawaban sebanyak 100\%. Sehingga dapat disimpulkan para penagih dalam melakukan penagihan selalu mendatangi langsung kepada pelanggan.

3. Penyerahan Hasil Penagihan

TABEL 9

Presentase Jawaban Responden Mengenai Penyerahan Hasil Penagihan Pada PT Adira Dinamika Multi Finance

\begin{tabular}{|c|c|c|c|c|c|c|c|c|c|c|}
\hline \multirow{2}{*}{ Pertanyaan } & \multicolumn{5}{|c|}{ Frekuensi Jawaban Berdasarkan Peringkat Jawabar } & \multicolumn{5}{|c|}{ Persentase Jawaban (\%) } \\
\hline & 5 & 4 & 3 & 2 & 1 & 5 & 4 & 3 & 2 & 1 \\
\hline P10 & 16 & 16 & 2 & 0 & 0 & 0.47 & 0.47 & 0.06 & 0.00 & 0.00 \\
\hline Total & 16 & 16 & 2 & 0 & 0 & 0.47 & 0.47 & 0.06 & 0.00 & 0.00 \\
\hline Rata-Rata & & & & & & 0.47 & 0.47 & 0.06 & 0.00 & 0.00 \\
\hline
\end{tabular}

Sumber: Diolah dari data primer

Berdasarkan tabel 9 diatas bahwa dari sejumlah responden sebanyak 34 orang sebanyak $0,47 \%$ menjawab sangat setuju, 0,47\% menjawab setuju dan sebanyak $0.06 \%$ menjawab ragu-ragu. Dengan demikian responden lebih 
banyak menjawab pada interval setuju dan sangat setuju dengan jumlah rata-rata jawaban sebanyak $0,94 \%$. Sehingga dalam prosedur penagihan ini para penagih senantiasa melakukan penyerahan atas hasil penagihan.

4. Evaluasi Hasil Penagihan dan Daftar Tagihan

TABEL 10

Presentase Jawaban Responden Mengenai Evaluasi Hasil Penagihan dan Daftar Tagihan

\begin{tabular}{|c|c|c|c|c|c|c|c|c|c|c|}
\hline \multirow{2}{*}{ Pertanyaan } & \multicolumn{6}{|c|}{ Frekuensi Jawaban Berdasarkan Peringkat Jawaban } & \multicolumn{4}{|c|}{ Persentase Jawaban (\%) } \\
\hline & 5 & 4 & 3 & 2 & 1 & 5 & 4 & 3 & 2 & 1 \\
\hline P11 & 14 & 10 & 10 & 0 & 0 & 0.41 & 0.29 & 0.29 & 0.00 & 0.00 \\
\hline Total & 14 & 10 & 10 & 0 & 0 & 0.41 & 0.29 & 0.29 & 0.00 & 0.00 \\
\hline Rata-Rata & & & & & & 0.41 & 0.29 & 0.29 & 0.00 & 0.00 \\
\hline
\end{tabular}

Sumber: Diolah dari data primer

Berdasarkan tabel 10 diatas bahwa dari sejumlah responden sebanyak 34 orang sebanyak $0,41 \%$ menjawab sangat setuju, 0,29\% menjawab setuju dan sebanyak 0,29\% menjawab ragu-ragu. Dengan demikian responden lebih banyak menjawab pada setuju dan sangat setuju yaitu sebanyak 70\%. Dalam mengevaluasi hasil penagihan dari data di atas masih ada yang melaksanakan evaluasi dari penagihan.

5. Penyerahan Daftar Tagihan Ke Bagian Piutang dan Akuntansi

Tabel 11

Presentase Jawaban Responden Mengenai Penyerahan Daftar Tagihan Ke Bagian Piutang dan Akuntansi

\begin{tabular}{ccccccccccc}
\hline \multirow{2}{*}{ Pertanyaan } & \multicolumn{1}{c}{ Frekuensi Jawaban Berdasarkan Peringkat Jawaban } & \multicolumn{5}{c}{ Persentase Jawaban (\%) } \\
\cline { 2 - 12 } & 5 & 4 & 3 & 2 & 1 & 5 & 4 & 3 & 2 & 1 \\
\hline P12 & 16 & 18 & 0 & 0 & 0 & 0.47 & 0.53 & 0.00 & 0.00 & 0.00 \\
\hline P13 & 14 & 14 & 6 & 0 & 0 & 0.41 & 0.41 & 0.18 & 0.00 & 0.00 \\
\hline P14 & 12 & 18 & 4 & 0 & 0 & 0.35 & 0.53 & 0.12 & 0.00 & 0.00 \\
\hline P15 & 16 & 16 & 2 & 0 & 0 & 0.47 & 0.47 & 0.06 & 0.00 & 0.00 \\
\hline Total & 58 & 66 & 12 & 0 & 0 & 1.71 & 1.94 & 0.35 & 0.00 & 0.00 \\
\hline Rata-Rata & & & & & & 0.43 & 0.49 & 0.09 & 0.00 & 0.00 \\
\hline
\end{tabular}

Sumber: Diolah dari data primer

Berdasarkan tabel 11 diatas bahwa dari sejumlah responden sebanyak 34 orang, sebanyak 0,43\% menjawab sangat setuju, 0,49\% menjawab setuju dan sebanyak 0.09\% menjawab ragu-ragu. Dengan demikian responden lebih banyak menjawab pada interval setuju dan sangat setuju dengan jumlah rata-rata jawaban sebanyak 0,49\%. Sehingga dalam dimensi ini para penagih selalu melakukan pelaporan dan penyerahan kembali daftar tahihan dan hasil penagihan kepada bagian piutang dan bagian akuntansi.

\section{Uji Statistik Chi-Square}

Analisis Pengaruh Peranan Internal Audit Terhadap Efektivitas Prosedur Penagihan Piutang Usaha PT Adira Dinamika Multi Finance Manado

Perhitungan nilai statistik pada penelitian ini, peneliti menggunakan uji statistik chi-square pada $\alpha=0,05$ dan $\mathrm{df}=1$ dengan batas kemaknaan $\mathrm{X}^{2}$ tabel $>3,84$ bila $\mathrm{X}^{2}$ hitung $>\mathrm{X}^{2}$ tabel yang berarti ada pengaruh atau hubungan yang bermakna (signifikan) dan apabila $\mathrm{X}^{2}$ hitung $<$ dari $\mathrm{X}^{2}$ tabel maka tidak ada pengaruh atau hubungan yang bermakna.

Peranan internal audit terhadap efektivitas prosedur penagihan piutang dapat di kategorikan menjadi dua kelompok baik ( ) dan kurang baik ( ) dengan jumlah responden 34 orang dapat dilihat pada tabel 12 dibawah ini :

TABEL 12

Pengaruh Peranan Internal Audit Terhadap Efektivitas Prosedur Penagihan Piutang Usaha PT Adira Dinamika Multi Finance

\begin{tabular}{|c|c|c|c|c|c|c|c|}
\hline \multirow{3}{*}{$\begin{array}{c}\text { Variabel Internal } \\
\text { Audit }\end{array}$} & \multicolumn{4}{|c|}{ Efektivitas Prosedur Penagihan Piutang Usaha } & \multirow{2}{*}{\multicolumn{2}{|c|}{ Jumlah }} & \multirow{3}{*}{ Kemaknaar } \\
\hline & \multicolumn{2}{|c|}{ Efektif } & \multicolumn{2}{|c|}{ Tidak Efektif } & & & \\
\hline & $\mathrm{n}$ & $\%$ & $\mathrm{n}$ & $\%$ & $\mathrm{~N}$ & $\%$ & \\
\hline Baik & 14 & 82.35 & 3 & 17.65 & 17 & 100 & \\
\hline Kurang Baik & 4 & 23.53 & 13 & 76.47 & 17 & 100 & $\begin{array}{r}=9,56 \\
\text { Bermakna }\end{array}$ \\
\hline Jumlah & 18 & & 16 & & 34 & & \\
\hline
\end{tabular}

Sumber: Data Olahan

Dari tabel 12 diatas dapat diketahui bahwa proporsi karyawan yang mengalami keefektifan prosedur penagihan piutang usaha yang peranan internal audit baik $82,35 \%$ dibandingkan dengan yang peranan internal auditnya kurang baik $23,53 \%$ yang mengalami keefektifan prosedur penagihan piutang usaha.

Dari hasil uji Chi-Square pada pada $\alpha=0,05$ dan $\mathrm{df}=1$ dimana $\mathrm{X}^{2}$ hitung $=9,56>\mathrm{X}^{2}$ tabel $=3,84$ ini berarti ada pengaruh atau hubungan yang bermakna antara peranan internal audit terhadap efektivitas prosedur penagihan piutang usaha. Dengan demikian hipotesis yang menyatakan bahwa ada pengaruh atau hubungan yang bermakna 
antara peranan internal audit terhadap efektivitas prosedur penagihan piutang usaha tepat terbukti. Hal ini menunjukan hipotesis alternatif (Ha) diterima dan hipotesis nol (Ho) ditolak.

\section{Kesimpulan}

\section{PENUTUP}

1. Pelaksanaan Peranan Internal Audit pada PT Adira Dinamika Multi Finance sangat memadai.

2. Dari hasil penelitian dapat dikatakan bahwa pelaksanaan efektivitas prosedur penagihan piutang usaha pada PT Adira Dinamika Multi Finance dikatakan sudah sangat efektif.

3. Adanya pengaruh atau hubungan yang bermakna antara peranan internal audit terhadap efektivitas prosedur penagihan piutang usaha PT Adira Dinamika Multi Finance dengan $\quad=9,56$. Hal ini berarti dengan adanya peranan internal audit yang baik, maka dapat menunjang efektifnya prosedur penagihan piutang usaha.

\section{Saran}

1. Bagi Pimpinan PT. Adira Dinamika Multi Finance: Bagi pimpinan PT Adira Dinamika Multi Finance disarankan agar dapat melaksanakan peranan internal auditnya dengan lebih baik lagi untuk dapat menunjang keefektifan prosedur penagihan piutang usaha perusahaan.

2. Bagi Peneliti: Pada penelitian yang akan datang agar dapat meneliti variabel-variabel yang belum diteliti sesuaikan dengan kondisi perusahaan yang diteliti.

\section{DAFTAR PUSTAKA}

Akbar. Rudi, (2004), Akuntansi Pengantar, UPP YKPN, Yogyakarta. http://vangaliputra.com/2011/05/definisipiutang.html, Diakses pada 18 November 2013

Akmal, (2006), Pemeriksaan Intern, Indeks, Indonesia.

Gitasudarmo. Indriyo \& Basri H, (2002), Manajemen Keuangan, Edisi 4, BPFE UGM. http://syafrizalhelmi.com/2008/06/kebijakan-piutang.html, Diakses pada 18 November 2013

Kasmir, (2003), Bank dan Lembaga Keuangan Lainnya, PT Raja Grafindo, Persada, Jakarta. http://syafrizalhelmi.com/2008/06/kebijakan-piutang.html, Diakses 18 November 2013

Kuncoro, Mudrajad. (2003). Metode Riset Untuk Bisnis Dan Ekonomi. Jakarta: Erlangga

Mahmudi, (2007), Manajemen Kinerja Sektor Publik, Yogyakarta:UPP STIM YKPN.

Mulyadi, (2007), Sistem Akuntansi, Edisi ke-tiga, Salemba Empat, Jakarta.

Randal J. Elder, Mark S. Beasley, Alvin A. Arens dan Amir Abadi Yusuf (2011), Jasa Audit Dan Issurance, Salemba Empat, Jakarta.

Soekrisno, Agoes. (2004). Auditing (Pemeriksaan Akuntan) oleh Kantor Akuntan Publik. Edisi Ketiga. Jakarta: Lembaga Penerbitan FEUI.

Sugiyono, (2008), Metode Penelitian Bisnis, Alfabeta, Bandung

Tugiman. Hiro, (2008), Standar Profesional Audit Internal, Kanisisus, Yogyakarta. 